\title{
Puna-apilan kehitysrytmi alku- ja loppukesällä
}

\author{
Kaisa Kuoppala $^{1)}$, Marketta Rinne ${ }^{1)}$, Mikko Tuori ${ }^{2,1)}$, Pirjo Pursiainen ${ }^{2)}$ ja Aila Vanhatalo ${ }^{2)}$ \\ ${ }^{1)}$ MTT, Kotieläintuotannon tutkimus, 31600 Jokioinen, etunimi.sukunimi@mtt.fi \\ ${ }^{2)}$ Helsingin yliopisto, Kotieläintieteen laitos, 00014 Helsingin yliopisto, etunimi.sukunimi@helsinki.fi
}

\section{Tiivistelmä}

Suomessa kasvukausi on lyhyt ja sen aikana nurmikasveissa tapahtuu suuria muutoksia: kevätkasvu on nopeaa ja laatu huononee kasvukauden edetessä samalla, kun nurmesta saatava sato lisääntyy. Nurmirehun korjuun ajoittaminen on tärkein sulavuuteen vaikuttava tekijä. Korjuuaikatutkimukset on tehty pääasiassa nurmiheinäkasveilla kevätsadosta. Puna-apilaa, joka on Suomen oloissa tärkein nurmipalkokasvi, on tutkittu paljon vähemmän. Se poikkeaa kehitysrytmiltään selvästi nurmiheinistä.

Kasvuston vanhetessa versojen morfologinen koostumus muuttuu eli varren osuus lisääntyy ja lehtien osuus vähenee, varsi kasvaa pituutta ja sen koostumus muuttuu. Varsi on huonommin sulavaa kuin lehdet, joten koko kasvin sulavuus huononee varren osuuden lisääntyessä. Tämän tutkimuksen tarkoituksena oli selvittää puna-apilakasvuston kehitystä ja koostumusta kasvun aikana ensimmäisessä ja toisessa sadossa.

Tutkimuksen aineiston kasvustonäytteet kerättiin viikoittain Siuntiosta, Jokioisilta, Vihdistä ja Viikistä puhtaista puna-apilakasvustoista vuosina 2002-2004. Näytteitä otettiin sekä ensikasvusta (4 kasvustoa, 36 kpl) että jälkikasvusta (10 kasvustoa, $41 \mathrm{kpl}$ ) useita kertoja. Näytteistä määritettiin kuiva-ainepitoisuus ja kemiallinen koostumus MTT:n ja HY:n laboratorioissa standardimenetelmin. Sulavuus määritettiin pepsiinisellulaasiliukoisuusmenetelmällä (OMS). Tuoreista kasvustonäytteistä tehtiin botaaninen ja morfologinen analyysi.

Tutkitut kasvustot sisälsivät keskimäärin 885 g/kg ka puna-apilaa eli olivat varsin puhtaita. Näytteiden D-arvo oli keskimäärin 668 g/kg ka ja kuiva-ainesato 3926 kg/ha. Varsien osuus apilasta oli keskimäärin 510, lehtien 463 ja kukintojen $26 \mathrm{~g} / \mathrm{kg}$ ka. Suurempi lehtien osuus ja pienempi varsien osuus olivat yhteydessä korkeampaan D-arvoon. Vaihtelu kaikissa havainnoiduissa ominaisuuksissa oli suurta kasvustojen ominaisuuksien ja kasvun etenemisen aiheuttamien muutosten takia.

D-arvo laski 1. sadon näytteissä 3,3 g ja 2. sadossa 1,9 g päivässä eli D-arvon lasku oli hitaampaa 2. sadossa. Lämpösumman kertyminen selitti kasvustojen D-arvon muutosta paremmin kuin kasvun etenemisen kuvaaminen kalenteriajan perusteella eri sadoissa samoin kuin aiemmin on havaittu nurmiheinäkasvustoissa. Lämpösumma-astetta kohti D-arvo laski 1 . sadossa $0,34 \mathrm{~g} /{ }^{\circ} \mathrm{Cvrk}$, joka on puolet siitä, mitä tyypillisesti nurmiheinillä havaitaan ja 2. sadossa $0,21 \mathrm{~g} /{ }^{\circ} \mathrm{Cvrk}$, joka on samalla tasolla kuin nurmiheinäkasvustoissa.

Puna-apila kehittyy hitaammin ja sen sulavuus laskee hitaammin alkukesästä nurmiheinäkasvustoihin verrattuna. Ensimmäisen ja toisen sadon väliset erot eivät puna-apilan kohdalla ole yhtä selvät kuin nurmiheinien. Puna-apilakasvuston kukinta ei näyttäisi liittyvän kasvuston kehitysasteeseen tai sulavuuden alenemiseen kasvun edetessä samalla lailla kuin nurmiheinäkasvustojen.
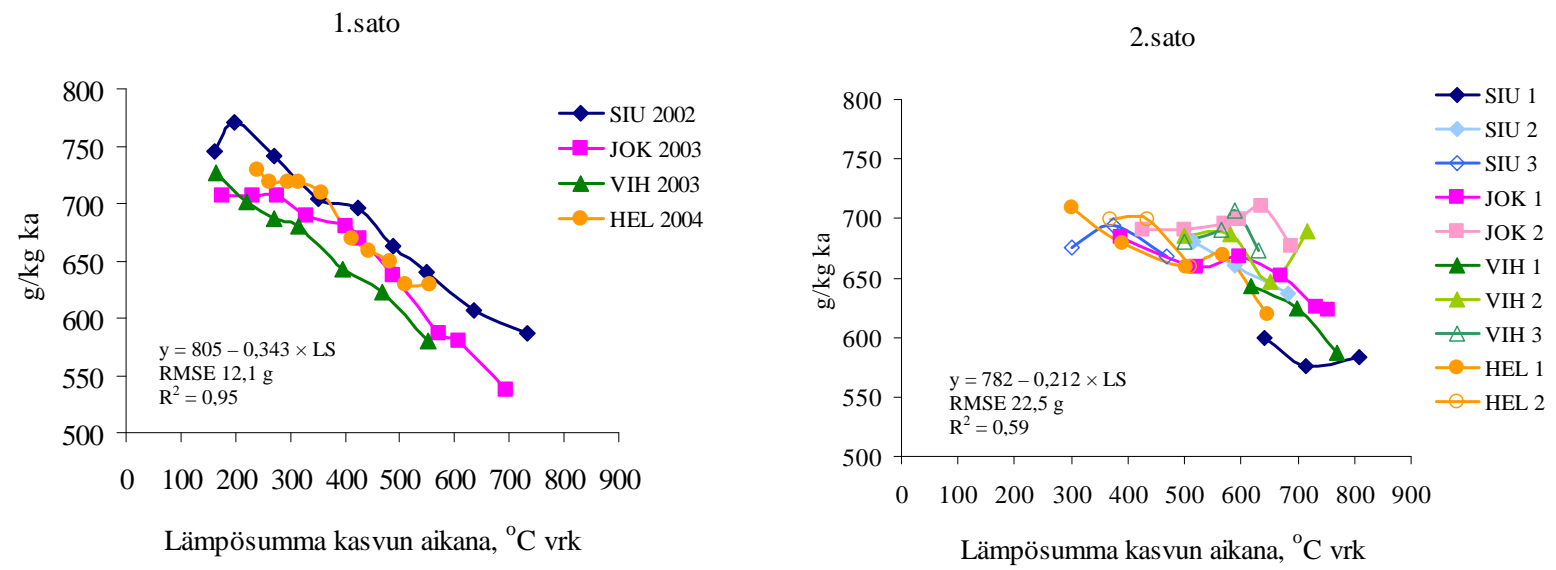

Kuva. Puna-apilakasvuston D-arvon kehitys 1. ja 2. sadossa. Paikkakunnat: SIU = Siuntio, JOK = Jokioinen, VIH = Vihti, HEL = Viikki, vuosiluku on näytteiden ottovuosi, numero 2.sadossa on ensikasvun korjuujärjestys.

Asiasanat: Puna-apila, korjuuaika, 1. sato, 2. sato, D-arvo, sulavuus, lämpösumma 


\section{Johdanto}

Suomessa kasvukausi on lyhyt ja sen aikana nurmikasveissa tapahtuu suuria muutoksia: kevätkasvu on nopeaa ja laatu huononee kasvukauden edetessä samalla, kun nurmesta saatava sato lisääntyy. Nurmirehun korjuun ajoittaminen on tärkein sulavuuteen vaikuttava tekijä. Korjuuaikatutkimukset on tehty pääasiassa nurmiheinäkasveilla. Puna-apilaa, joka on Suomen oloissa tärkein nurmipalkokasvi, on tutkittu vähemmän. Se poikkeaa kehitysrytmiltään selvästi nurmiheinistä. Lypsylehmillä tehdyssä fysiologisessa kokeessa todettiin, että korjuun myöhästyttäminen ei vaikuta puna-apilasäilörehun syöntiin yhtä systemaattisesti ja selvästi kuin nurmiheinäkasveista tehdyn säilörehun (Vanhatalo ym. 2009, Kuoppala ym. 2009). Lehmät söivät enemmän myöhemmin korjattua puna-apilasäilörehua, kun taas timoteinurminatasäilörehun syöntiä myöhempi korjuu vähensi.

Nurmikasvustojen kehitystä on tutkittu eniten kevätsadosta eli kesän ensimmäisestä korjuusta. Toisen sadon kehityksen tutkiminen on kuitenkin tärkeää, sillä toisen sadon rehu muodostaa suuren osan lypsylehmien vuoden rehuannoksesta. Toisen sadon kehitys on hyvin erilaista verrattuna ensimmäiseen satoon, sillä lämpötila on korkeampi ja toisen sadon kasvuajan pituus ja ajankohta kesässä riippuvat suuresti 1. sadon korjuuajankohdasta. Nurmiheinäkasveilla on todettu, että kasvuston kehitys on noin kaksi kertaa nopeampaa kevään ensikasvussa verrattuna jälkikasvuun eli 2. satoon (Kuoppala ym. 2003; Sihto ja Rinne 2008) ja versotyypit ovat erilaisia (Pakarinen ym. 2008).

Kasvuston vanhetessa versojen morfologinen koostumus muuttuu eli varren osuus lisääntyy ja lehtien osuus vähenee, varsi kasvaa pituutta ja sen koostumus muuttuu. Varsi on huonommin sulavaa kuin lehdet, joten koko kasvin sulavuus huononee varren osuuden lisääntyessä. Tämän tutkimuksen tarkoituksena oli selvittää puna-apilakasvuston kehitystä ja koostumusta kasvun aikana ensimmäisessä ja toisessa sadossa.

\section{Aineisto ja menetelmät}

Tutkimuksen kasvustonäytteet kerättiin viikoittain Siuntiosta, Jokioisilta, Vihdistä ja Viikistä puhtaista punaapilakasvustoista vuosina 2002-2004. Näytteitä otettiin sekä ensikasvusta (4 kasvustoa, 36 kpl) että jälkikasvusta (10 kasvustoa, $41 \mathrm{kpl})$ useita kertoja. Näytteenotto aloitettiin hyvin aikaisessa vaiheessa, Siuntiossa toukokuun lopulla ja muualla kesäkuun alussa ja näytteitä otettiin hyvin myöhäiselle asteelle asti, yli tavanomaisen säilörehun korjuuajankohdan. Kasvustoista tehtiin myös säilörehuja sulavuuskokeita varten (Kuoppala ym. 2006). Puna-apilalajikkeena Siuntiossa oli Björn, Jokioisilla ja Vihdissä Jokioinen sekä Viikissä Varte.

Näytteet otettiin $0,25 \mathrm{~m}^{2}$ kehikolla vähintään 4 kehikollista kerrallaan. Näytteet punnittiin tuoreena sadon määrän laskemista varten. Näytteistä määritettiin kuiva-aineen (ka) pitoisuus ja kemiallinen koostumus MTT:n ja HY:n laboratorioissa standardimenetelmin. Sulavuus määritettiin pepsiini-sellulaasiliukoisuusmenetelmällä (OMS) joko Valiolla Nousiaisen ym. (2003) menetelmällä tai MTT:Ilä sen modifikaatiolla käyttäen Trichoderma viriden (Onozuka R-10, Yakulta Pharmaceutical Ltd, Japani) sellulaasientsyymiä. Orgaanisen aineen sulavuus (OMD) laskettiin OMS:stä käyttäen sulavuuskoeaineistosta puna-apilalle määrittyä empiiristä korjausyhtälöä (Rinne ym. 2008a). Sulavan orgaanisen aineen pitoisuus kuiva-aineessa eli D-arvo (g/kg ka) laskettiin OMD:stä näytteen tuhkapitoisuuden perusteella. Yhden kokeen näytteistä $(\mathrm{n}=18)$ määritettiin D-arvo NIR-menetelmällä.

Tuoreista kasvustonäytteistä määritettiin puna-apilan, muiden kasvien ja kuolleiden kasvinosien osuudet (botaaninen analyysi) ja sen jälkeen puna-apilasta edelleen eroteltiin lehdet, varret ja nuput tai kukat (morfologinen analyysi). Jokioisten näytteistä määritettiin myös lehtien ja varsien sulavuudet erikseen.

Kasvuston kehitystä tutkittiin lineaarisella regressioanalyysillä SAS:n mixed-proseduurilla niin, että koepaikka oli mallissa mukana satunnaistekijänä: $\mathrm{Y}_{\mathrm{ijkl}}=\mathrm{A}_{0}+$ Paikka $_{\mathrm{i}}+$ Sato $_{\mathrm{j}}+\mathrm{B}_{1} \mathrm{X}_{\mathrm{ijk}}+\mathrm{e}_{\mathrm{ijk}}$, missä $\mathrm{A}_{0}$ on vakio (kiinteä tekijä), Paikka $a_{i}$ on koepaikan satunnaisvaikutus, $S a_{0}$ on sadon vaikutus, $\mathrm{B}_{1}$ on regressiokerroin ja $e_{\mathrm{ijk}}$ on virhetermi. Selitettävänä Y-muuttujana olivat D-arvo, OMD, NDF tai raakavalkuaispitoisuus ja selittävänä X-muuttujana kasvupäivien lukumäärä, lämpösumma kasvun aikana, lehtien osuus tai varsien osuus. Mallien vertailu tehtiin käyttämällä mallin selitysastetta (Adj. $\mathrm{R}^{2}$ ) ja virhetermiä (Residual Mean Square Error, RMSE). Koepaikka sisältää kokeiden välisen vaihtelun (yhdellä paikkakunnalla tehdyt säilörehut tutkittiin samassa kokeessa ja näytteet analysoitiin samalla kertaa samoissa laboratorioissa) lisäksi eri paikkakuntien erilaiset sääolot ja muut kasvuolosuhteet. Regressioanalyysit tehtiin koko aineistosta sekä erikseen eri sadoista. 


\section{Tulokset ja tulosten tarkastelu}

Puna-apilakasvustonäytteitä kerättiin yhteensä 77 kappaletta, joista 1. satoa oli 36 ja 2. satoa 41 näytettä (taulukko 1). Tutkitut kasvustot sisälsivät keskimäärin 885 g/kg ka puna-apilaa eli olivat varsin puhtaita. Näytteiden D-arvo oli molemmissa sadoissa keskimäärin 667 g/kg ka. Keskimääräinen kuiva-ainesato oli 1. sadossa suurempi kuin 2. sadossa (4757 vs. 3196 kg/ha). Kasvuston NDF- ja raakavalkuaispitoisuudet olivat suuremmat 2. sadossa. Vaihtelu kaikissa havainnoiduissa ominaisuuksissa oli suurta kasvustojen ominaisuuksien ja kasvun etenemisen aiheuttamien muutosten takia. Vaihtelu oli myös suurempaa 1. sadon näytteissä kuin 2. sadon näytteissä. Regressioanalyysin virhetermi oli suurempi ja selitysaste pienempi, kun aineisto käsiteltiin yhtenä kokonaisuutena. Kun analyysi tehtiin sadoittain, virhe pieneni ja selitysaste parani.

Morfologinen analyysi eli varsien, lehtien ja kukkien osuudet määritettiin 59 näytteestä. Varsien osuus lisääntyi ja lehtien osuus vähentyi kasvukauden edetessä (kuvat 1 ja 2) sekä ensikasvussa että jälkikasvussa. Lehtien osuus oli 2. sadon näytteissä keskimäärin suurempi verrattuna 1. satoon. Jälkikasvussa kasvin morfologiseen kehityksen kannalta ensimmäisen niiton ajankohta on merkityksellinen. Sen perusteella kasvuston kasvamisajankohta sijoittuu kesän eri vaiheisiin ja erilaisiin lämpötila- ja sadeolosuhteisiin. Kun ensimmäinen sato oli korjattu myöhään, jälkikasvu oli lehtevämpää. Kukkia näytteissä oli vähän erityisesti 1. sadossa ja kukinta alkoi 1. sadossa Jokioisissa vasta heinäkuulla. Toisen sadon kasvusto alkoi kukkia aikaisemmin ja kukkia oli enemmän. Fagerbergin (1988) mukaan 2. sadon puna-apila alkaa kukkia jäljelle jääneistä varsista aikaisin samalla, kun kasvusto yleisesti on nuorta, kasvussa olevaa ja lehtien osuus on suuri. Framen (1998) mukaan puna-apilan kukinta ei liity kasvuston sulavuuden alenemiseen samalla lailla kuin nurmiheinäkasvustoissa eikä korjuupäätöstä sen vuoksi kannattane tehdä pelkästään kasvuston kukinnan perusteella.

D-arvo laski 1. sadon näytteissä 3,3 g/kg ka päivässä (taulukko 2, kuva 3). Tämä on hieman korkeampi kuin heinäkasvien kanssa seoksena kasvaneella puna-apilalla (2.6 g/d Rinne ja Nykänen, 2000; 2,9 g/d Rinne ym., 2007). Lämpösumman kertyminen selitti 1. sadon kasvustojen D-arvon muutosta paremmin kuin kasvun etenemisen kuvaaminen kalenteriajan perusteella (RMSE 12,1 vs. 16,2 g/kg KA) samoin kuin aiemmin on havaittu nurmiheinäkasvustoissa. Lämpösumman kulmakerroin oli pienempi (D-arvon lasku 0,34 g/kg ka yhtä lämpösumma-astetta kohti) kuin, mitä tyypillisesti nurmiheinillä havaitaan eli puna-apilan keskimääräinen kehitysrytmi on alkukesällä nurmiheiniä hitaampi. Kulmakerroin oli samaa luokkaa kuin Rinteen ym. (2007) tuloksissa $\left(0,32 \mathrm{~g} /{ }^{\circ} \mathrm{C}\right.$ vrk) seoskasvustossa kasvaneen puna-apilan.

Toisessa sadossa D-arvon lasku oli melkein puolet hitaampaa kuin 1. sadossa (1,9 g/kg ka päivässä) (taulukko 2.). Lämpösumman kulmakerroin ja selitysaste olivat pienemmät kuin 1 . sadossa (-0,21 vs. $-0,34$ $\mathrm{g} / \mathrm{kg}$ ka ja $\mathrm{R}^{2}$ 0,59 vs. 0,95). D-arvon lasku 2. sadossa oli tässä kokeessa paljon suurempi kuin Rinteen ym. (2007) seoskasvustojen puna-apilalla ja vastasi nurmiheinäkasvuston 2. sadossa havaittua arvoja (Sihto ja Rinne 2008). Lämpösummaa paremmin tässä aineistossa D-arvon muutosta kuvasi 2. sadossa lehtien osuus (RMSE 19,4 ja $\mathrm{R}^{2}$ 0,75). Verrattuna 1. satoon, 2. sadon tuloksissa vaihtelu oli suurempaa ja ensikasvun ajankohdalla oli niihin suuri vaikutus.

Kuiva-ainesadon määrä lisääntyi nopeammin ensikasvussa kuin jälkikasvussa (177 vs. 99 kg ka/pv) (taulukko 2, kuva 4). NDF-pitoisuus lisääntyi kaksi kertaa nopeammin 1. sadossa verrattuna 2. satoon (3,7 vs. 1,6 g/pv) kasvuajan edetessä.

Lehdet ja varret analysoitiin erikseen Jokioisten näytteistä (n=22). Lehtien D-arvo pysyi yli $700 \mathrm{~g} / \mathrm{kg}$ ka koko näytteenottoajan, kun taas varsien D-arvo laski alle 600 g/kg ka (kuva 5). Koko kasvin D-arvo laski käyräviivaisesti eli hitaan alun (0,75 g/pv neljän ensimmäisen näytteenottokerran aikana) jälkeen lasku oli nopeampaa (6,73 g/pv kuuden seuraavan näytteenottokerran aikana) varsien osuuden lisääntyessä. Muilla koepaikoilla sulavuuden lasku kasvun edetessä oli lineaarisempaa (kuva 3). Kasvuston sulavuuden lasku johtuu varsien osuuden lisääntymisestä ja lehtien osuuden vähenemisestä sekä varsien sulavuuden laskusta.

Puna-apilaa viljellään yleensä nurmiheinäkasvien kanssa seoksina, jonka vuoksi korjuuaikapäätöstä tehtäessä on huomioitava puna-apilan ja heinäkasvien osuudet. Heinäkasvien sulavuus laskee korjuun myöhästyessä myös seoskasvustossa. Jos puna-apilan osuus on suuri, korjuuta voi myöhästyttää puhtaisiin heinäkasvinurmiin verrattuna. ARTTURI ${ }^{\circledR}$-verkkopalvelun korjuuaikatiedotuksessa ennustetaan myös puna-apilaja seosnurmien D-arvon kehitystä lämpösummaan perustuen.

\section{Johtopäätökset}

Puna-apila kehittyy hitaammin ja sen sulavuus laskee hitaammin alkukesällä nurmiheinäkasvustoihin verrattuna. Ensimmäisen ja toisen sadon väliset erot eivät puna-apilan kohdalla ole yhtä selvät kuin nurmiheinillä. Puna-apilakasvuston kukinta ei näytä liittyvän kasvuston kehitysasteeseen tai sulavuuden alenemiseen kasvun edetessä samalla lailla kuin nurmiheinäkasvustojen. 
Taulukko 1. Puna-apilan kasvustonäyteaineiston kuvailu.

\begin{tabular}{|c|c|c|c|c|c|c|}
\hline & Sato & $\mathrm{n}$ & Keskiarvo & Keskihajonta & Minimi & Maksimi \\
\hline \multirow[t]{2}{*}{ Lämpösumma ${ }^{1)}$} & 1 & 36 & 396 & 153,8 & 162 & 734 \\
\hline & 2 & 41 & 571 & 128,7 & 301 & 810 \\
\hline \multirow[t]{2}{*}{ Kasvuaika $^{2)}$, pv } & 1 & 36 & 54 & 15,6 & 21 & 81 \\
\hline & 2 & 41 & 45 & 12,2 & 21 & 68 \\
\hline \multirow[t]{2}{*}{ Lämpösumma/kasvupäivä } & 1 & 36 & 7,2 & 1,07 & 5,1 & 9,5 \\
\hline & 2 & 41 & 13,0 & 1,16 & 11,1 & 15,8 \\
\hline \multirow[t]{2}{*}{ Kuiva-aine, g/kg } & 1 & 36 & 152 & 34,9 & 102 & 260 \\
\hline & 2 & 41 & 187 & 55,6 & 104 & 297 \\
\hline \multirow[t]{2}{*}{ Raakavalkuainen, g/kg ka } & 1 & 26 & 193 & 38,3 & 129 & 263 \\
\hline & 2 & 33 & 201 & 33,0 & 135 & 262 \\
\hline \multirow[t]{2}{*}{ NDF, g/kg ka } & 1 & 26 & 357 & 71,9 & 246 & 483 \\
\hline & 2 & 33 & 367 & 59,8 & 263 & 495 \\
\hline \multirow[t]{2}{*}{ Kuiva-ainesato kg ka/ha } & 1 & 36 & 4757 & 2818,0 & 800 & 10627 \\
\hline & 2 & 41 & 3196 & 1647,5 & 983 & 8014 \\
\hline \multirow[t]{2}{*}{ Apilan osuus näytteestä, g/kg ka } & 1 & 26 & 896 & 107,8 & 621 & 987 \\
\hline & 2 & 33 & 877 & 64,0 & 682 & 971 \\
\hline \multirow[t]{2}{*}{ Varsien osuus näytteestä, g/kg ka } & 1 & 26 & 564 & 169,1 & 220 & 782 \\
\hline & 2 & 33 & 468 & 125,1 & 266 & 695 \\
\hline \multirow[t]{2}{*}{ Lehtien osuus näytteestä, g/kg ka } & 1 & 26 & 422 & 183,0 & 169 & 780 \\
\hline & 2 & 33 & 495 & 161,8 & 120 & 734 \\
\hline \multirow[t]{2}{*}{ Kukkien tai nuppujen osuus, g/kg ka } & 1 & 26 & 14 & 30,1 & 0 & 133 \\
\hline & 2 & 33 & 36 & 52,7 & 0 & 215 \\
\hline \multirow[t]{2}{*}{$\mathrm{OMD}^{3)}, \mathrm{g} / \mathrm{kg}$} & 1 & 26 & 746 & 74,0 & 604 & 854 \\
\hline & 2 & 32 & 743 & 56,2 & 601 & 812 \\
\hline \multirow[t]{2}{*}{ D-arvo, g/kg ka } & 1 & 36 & 667 & 59,2 & 550 & 753 \\
\hline & 2 & 40 & 667 & 49,5 & 546 & 734 \\
\hline
\end{tabular}

${ }^{1)}$ Lämpösumma laskettu termisen kasvukauden alusta 1. sadossa ja edellisestä korjuusta 2. sadossa;

${ }^{2)}$ Kasvuaika laskettu toukokuun alusta 1. sadossa ja edellisestä korjuusta 2. sadossa;

3) Orgaanisen aineen sulavuus, laskettu puna-apilan omalla kaavalla OMD = 0,003 + 0,93×OMS

Taulukko 2. Puna-apilan kasvustonäytteiden D-arvon, OMD:n, NDF:n ja raakavalkuaispitoisuuden (g/kg ka) ennustaminen käyttäen mixed regressioanalyysiä.

\begin{tabular}{lccccccc}
\hline Y-muuttuja: X-muuttuja & Sato & Vakio A & \multicolumn{1}{c}{ s.e. ${ }^{1}$} & kerroin B & \multicolumn{1}{l}{ s.e. } & RMSE $^{2}$ & Adj.R $^{2}$ \\
\hline D-arvo: Kasvupäivät & 1 & 847 & 9,89 & $-3,283$ & 0,1757 & 16,24 & 0,9086 \\
& 2 & 747 & 15,12 & $-1,914$ & 0,3286 & 25,22 & 0,4578 \\
D-arvo: Lämpösumma & $1+2$ & 781 & 11,86 & $-2,332$ & 0,2319 & 29,55 & 0,5698 \\
& 1 & 805 & 5,65 & $-0,343$ & 0,0133 & 12,11 & 0,9499 \\
& 2 & 782 & 16,24 & $-0,212$ & 0,0279 & 22,49 & 0,5918 \\
D-arvo: Lehtien osuus & $1+2$ & 765 & 11,27 & $-0,201$ & 0,0220 & 31,35 & 0,5239 \\
& 1 & 545 & 13,64 & 0,289 & 0,0297 & 27,20 & 0,7889 \\
& 2 & 563 & 11,04 & 0,207 & 0,0213 & 19,43 & 0,7504 \\
D-arvo: Varsien osuus & $1+2$ & 552 & 9,91 & 0,248 & 0,0201 & 26,53 & 0,7262 \\
& 1 & 833 & 22,71 & $-0,295$ & 0,0387 & 32,67 & 0,6953 \\
OMD: Kasvupäivät & 2 & 781 & 16,80 & $-0,248$ & 0,0345 & 24,34 & 0,6193 \\
& $1+2$ & 797 & 14,69 & $-0,256$ & 0,0275 & 31,79 & 0,6000 \\
NDF: Kasvupäivät & 1 & 965 & 17,85 & $-4,032$ & 0,3159 & 26,80 & 0,8662 \\
& 2 & 851 & 22,11 & $-2,417$ & 0,4624 & 31,54 & 0,4592 \\
& $1+2$ & 898 & 16,61 & $-3,118$ & 0,3201 & 36,09 & 0,6222 \\
Raakavalkuainen: Kasvupäivät & 1 & 158 & 21,35 & 3,697 & 0,378 & 32,06 & 0,7911 \\
& 2 & 298 & 22,09 & 1,597 & 0,4606 & 31,53 & 0,2562 \\
& $1+2$ & 234 & 18,22 & 2,631 & 0,3511 & 39,59 & 0,4875 \\
& 2 & 260 & 12,75 & $-1,991$ & 0,226 & 19,14 & 0,7545 \\
& $1+2$ & 286 & 12,71 & $-1,456$ & 0,265 & 18,14 & 0,4770 \\
\hline 1 Keskivin & 9,07 & $-1,808$ & 0,175 & 19,70 & 0,6464 \\
\hline
\end{tabular}

${ }^{1}$ Keskivirhe (standard error).

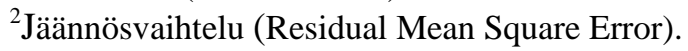

Kaikki vakioiden ja kulmakertoimien arvot olivat merkitseviä $P<0,001$ 

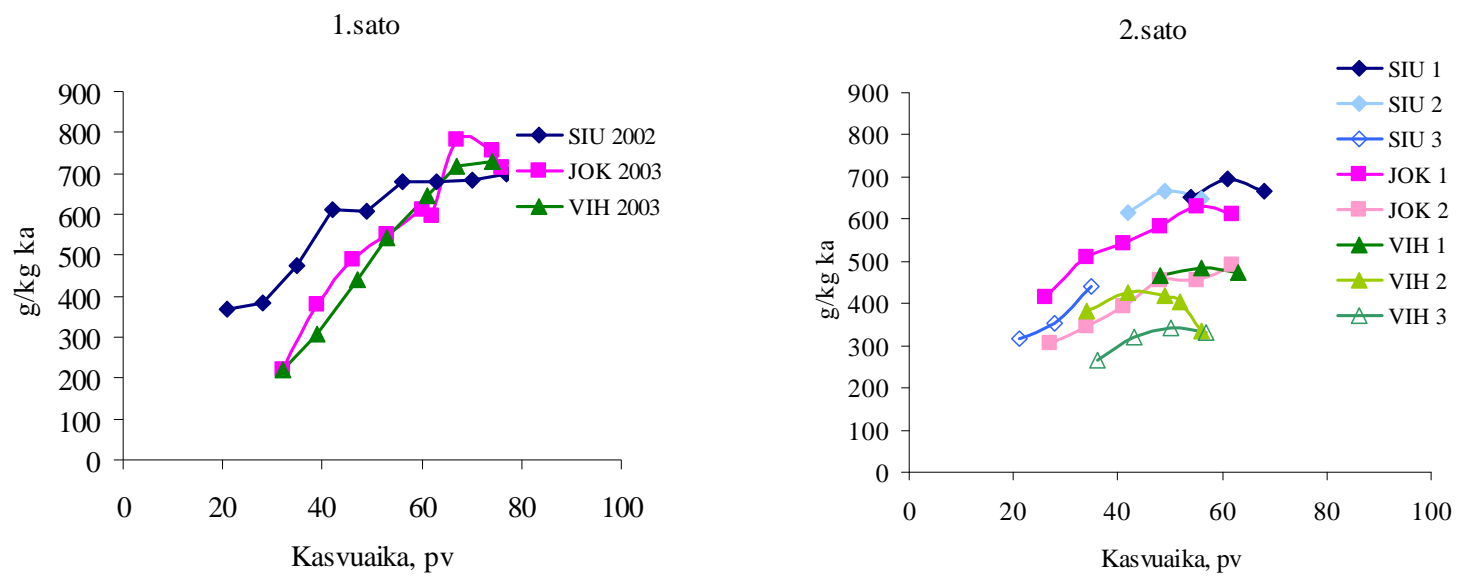

Kuva 1. Varsien osuuden lisääntyminen 1. ja 2. sadossa kasvun edetessä. Kasvuaika on laskettu toukokuun alusta 1. sadossa ja edellisestä korjuusta 2. sadossa. Paikkakunnat: SIU = Siuntio, JOK = Jokioinen, VIH = Vihti, HEL = Viikki, vuosiluku on näytteiden ottovuosi, numero 2.sadossa on ensikasvun korjuujärjestys.
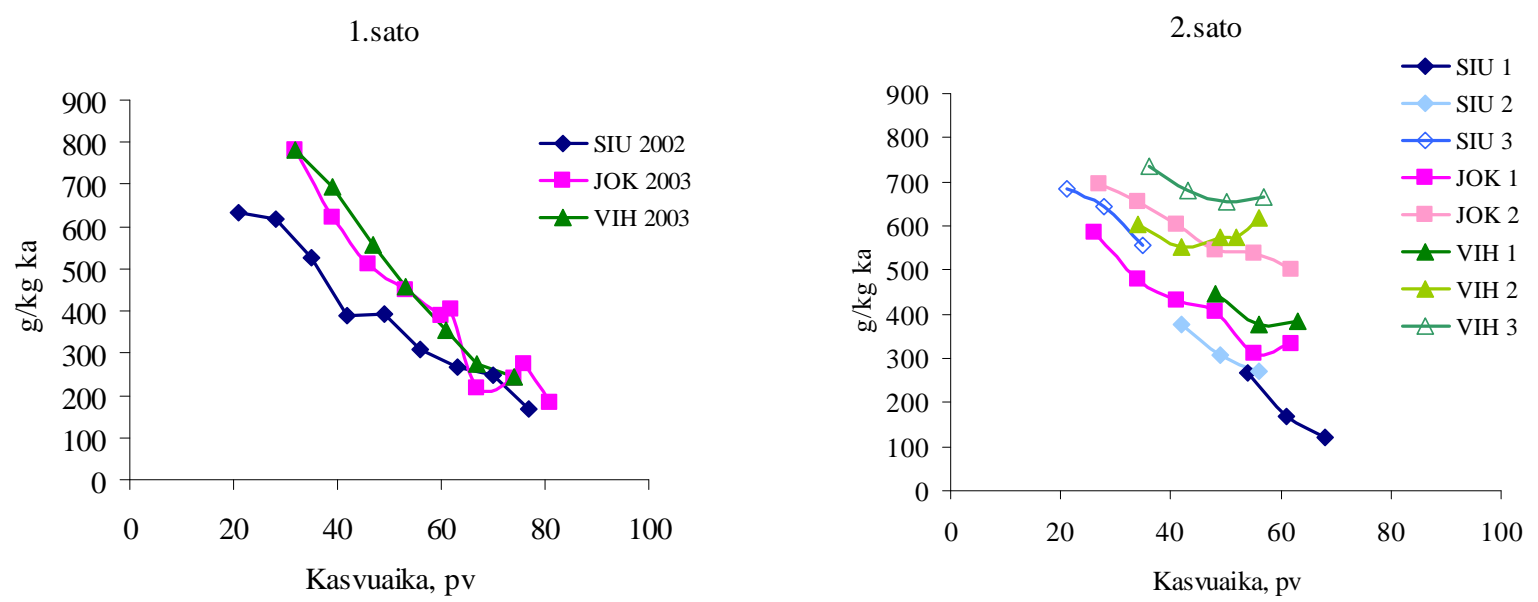

Kuva 2. Lehtien osuuden väheneminen 1. ja 2. sadossa kasvun edetessä. Kasvuaika on laskettu toukokuun alusta 1. sadossa ja edellisestä korjuusta 2. sadossa. Paikkakunnat: SIU = Siuntio, JOK = Jokioinen, VIH = Vihti, HEL = Viikki, vuosiluku on näytteiden ottovuosi, numero 2.sadossa on ensikasvun korjuujärjestys.
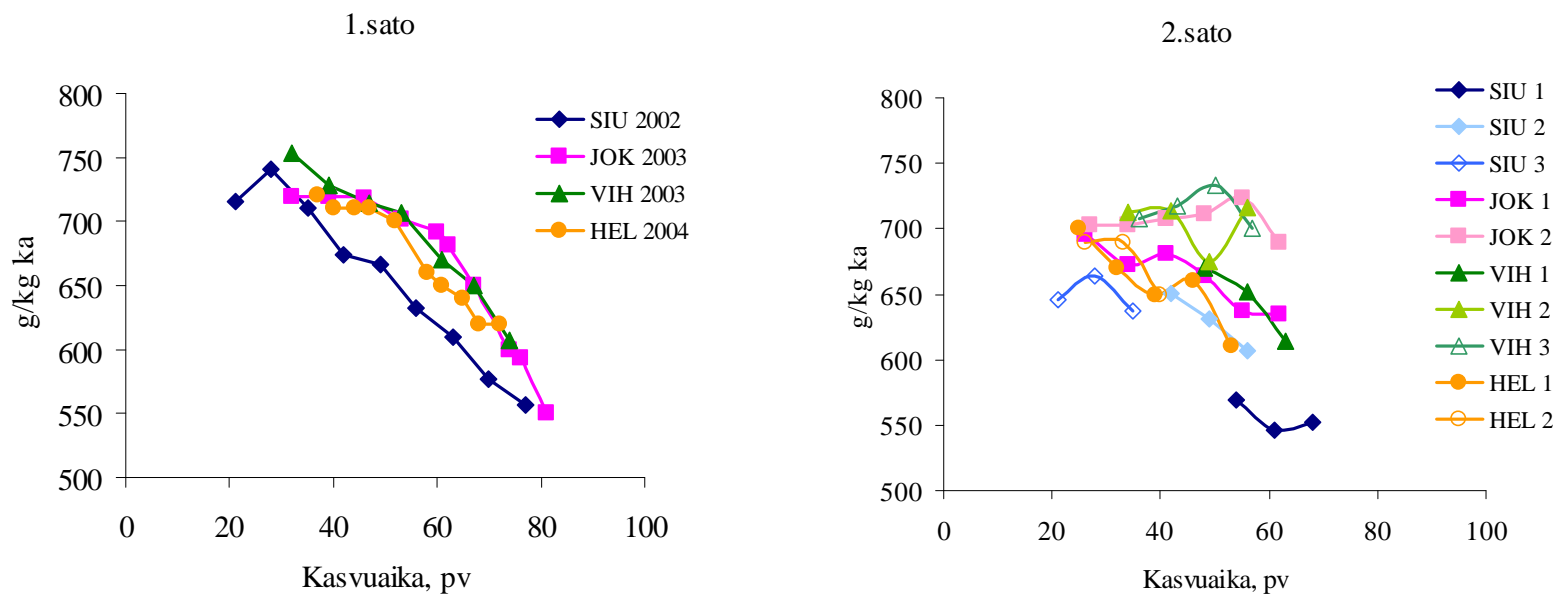

Kuva 3. D-arvon muutos 1. ja 2. sadossa kasvun edetessä. Kasvuaika on laskettu toukokuun alusta 1. sadossa ja edellisestä korjuusta 2. sadossa. Paikkakunnat: SIU = Siuntio, JOK = Jokioinen, VIH = Vihti, HEL = Viikki, vuosiluku on näytteiden ottovuosi, numero 2.sadossa on ensikasvun korjuujärjestys. 

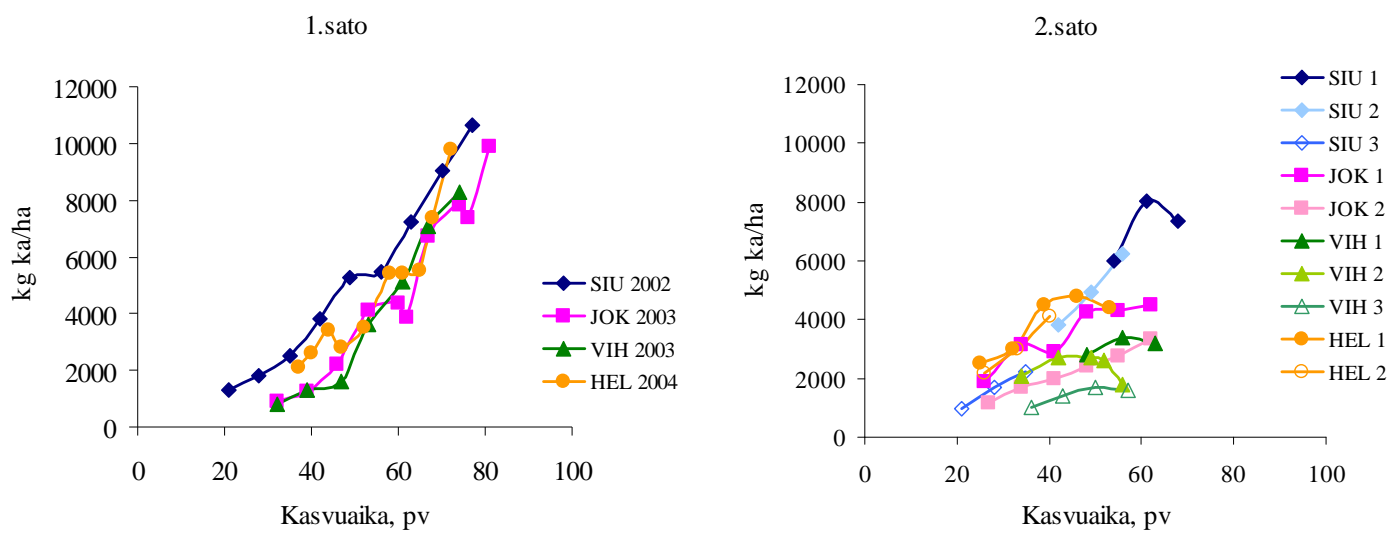

Kuva 4. Puna-apilakasvuston kuiva-ainesadon kehitys 1. ja 2. sadossa kasvun edetessä. Kasvuaika on toukokuun alusta 1. sadossa ja edellisestä korjuusta 2. sadossa. Paikkakunnat: SIU = Siuntio, JOK = Jokioinen, VIH = Vihti, HEL = Viikki, vuosiluku on näytteiden ottovuosi, numero 2. sadossa on ensikasvun korjuujärjestys.

D-arvo, g/kg ka

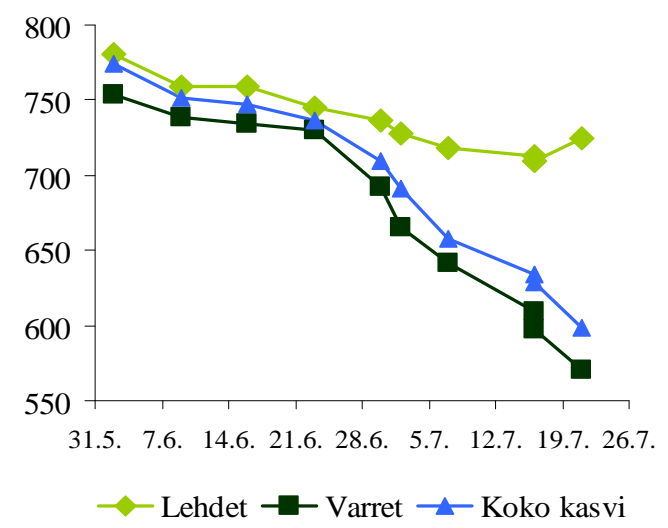

Lehtien,varsien ja kukkien osuudet, g/kg ka

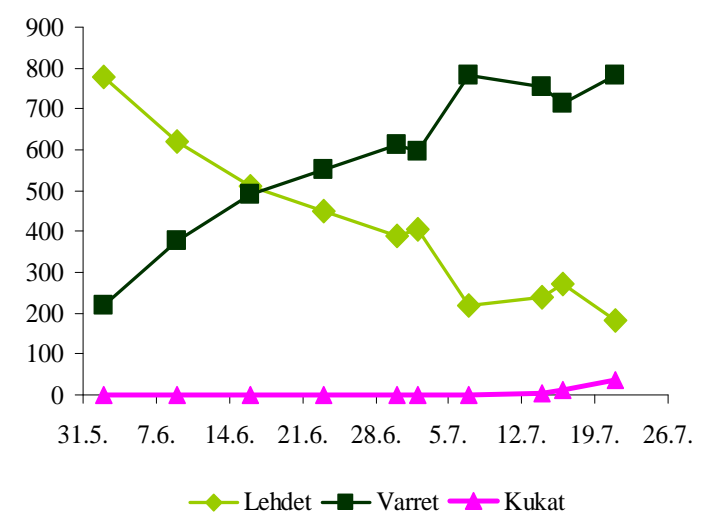

Kuva 5. Puna-apilakasvuston varsien ja lehtien D-arvojen sekä varsien ja lehtien osuuksien muutos Jokioisilta otetuissa 1. sadon näytteissä v. 2003.

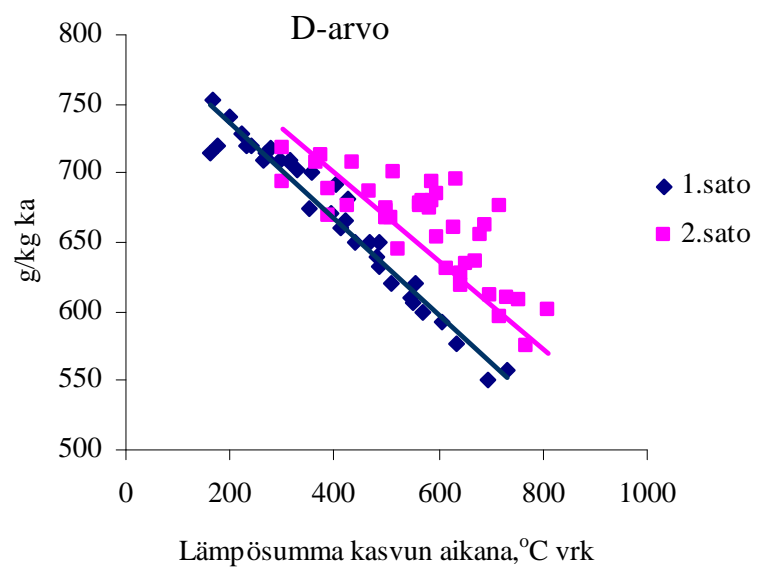

Kuva 6. Puna-apilakasvuston D-arvon kehitys. Regressioyhtälöt: 1 . sadossa D-arvo (g/kg ka) = 805 - 0,343 × LS (RSME 12.1 ja $\mathrm{R}^{2}$ 0.95) ja 2. sadossa D-arvo (g/kg ka) = 782 - 0,212 × LS (RMSE 22.5 ja R² 0.59).

Kirjallisuus 

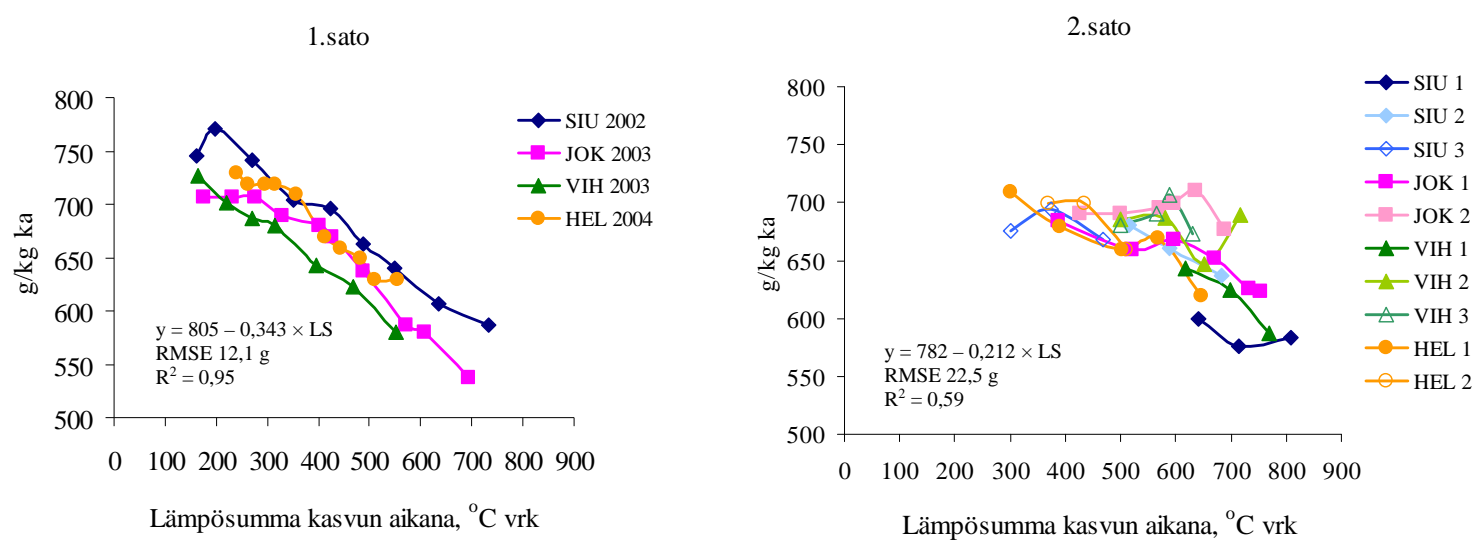

Kuva 7. Puna-apilakasvuston D-arvon kehittyminen 1. ja 2. sadossa näytteenottosarjoittain.

Fagerberg, B. 1988. Phenological development in timothy, red clover and lucerne. Acta Agric. Scand. 38: 159-170. Frame, J., Charlton, J. F. L. \& Laidlaw, A. S. 1998. Temperate Forage Legumes. Cab International, Wallingford, UK. 327 p.

Kuoppala, K., Ahvenjärvi, S., Rinne, M. \& Vanhatalo, A. 2009. Effects of feeding grass or red clover silage cut at two maturity stages in dairy cows. 2. Dry matter intake and cell wall digestion kinetics. J. Dairy Sci. 92: 5634-5644.

Kuoppala, K., Rinne, M., \& Huhtanen, P. 2003. Morphological composition and digestibility of primary growth and regrowth of timothy. Julkaisussa: Oiva Niemeläinen and Mari Topi-Hulmi (toim.). Proceedings of the NJF's 22nd congress 'Nordic Agriculture in Global Perspective', July 1-4, 2003, Turku, Finland. Jokioinen: MTT Agrifood Research Finland, NJF.

Kuoppala, K., Rinne, M., Tuori, M., Pursiainen, P. \& Vanhatalo, A. 2006. Puna-apilasäilörehujen sulavuuden määrittäminen. Julkaisussa: Maataloustieteen Päivät 2006 [verkkojulkaisu]. Suomen Maataloustieteellisen Seuran julkaisuja no 21. Toim. Anneli Hopponen. Viitattu 5.11.2009. Julkaistu 9.1.2006. Saatavilla Internetissä:

http://www.smts.fi/pos06/1108.pdf

Nousiainen, J., Rinne, M., Hellämäki, M., \& Huhtanen, P. 2003. Prediction of the digestibility of the primary growth of grass silages harvested at different stages of maturity from chemical composition and pepsin-cellulase solubility. Animal Feed Science and Technology 103: 97-111.

Rinne, M., Huhtanen, P., \& Nousiainen, J. 2008a. Karkearehujen sulavuuden määritys tarkentunut. Julkaisussa: Maataloustieteen Päivät 2008 [verkkojulkaisu]. Suomen Maataloustieteellisen Seuran tiedotteita no 23. Toim. Anneli Hopponen. Julkaistu 9.1.2008. Saatavilla Internetissä: http://www.smts.fi/mpol2008/index_tiedostot/Posterit/ps024.pdf.

Rinne, M. \& Nykänen, A. 2000. Timing of primary growth harvest affects the yield and nutritive value of timothy-red clover mixtures. Agricultural and Food Science in Finland 9: 121-134.

Rinne, M., Nykänen, A., Nyholm, L., Nousiainen, J. \& Vanhatalo, A. 2007. Kehitysrytmi huomioitava apilanurmen korjuussa. Puna-apilaa nurmiin ja ruokintapöydälle. Puna-apila tehokkaasti luomumaidoksi -tutkimushankkeen päätösseminaari 17.4.2007. Toim. A. Vanhatalo \& M. Topi-Hulmi. Suomen Nurmiyhdistyksen julkaisuja 25: 23-33. Saatavilla Internetissä: https://portal.mtt.fi/portal/page/portal/nurmiyhdistys/Julkaisut/punaapila/rinne.pdf

Sihto, U. \& Rinne, M. 2008. Nurmen kasvumallin kehitys kainuulaisella aineistolla. Julkaisussa: Maataloustieteen Päivät 2008 [verkkojulkaisu]. Suomen Maataloustieteellisen Seuran tiedotteita no 23. Toim. Anneli Hopponen. Julkaistu 9.1.2008. Saatavilla Internetissä: http://www.smts.fi/mpol2008/index_tiedostot/Posterit/ps022.pdf

Vanhatalo, A., Kuoppala, K., Ahvenjärvi, S. \& Rinne, M. 2009. Effects of feeding grass or red clover silage cut at two maturity stages in dairy cows. 1. Nitrogen metabolism and supply of amino acids. J. Dairy Sci. 92: 5620-5633. 